Volume 1 Nomor 1, Juli-Desember 2017: hlm. 29-38. Magister Ilmu Hukum, Fakultas Hukum, Universitas Lampung, Bandar Lampung, Lampung, Indonesia. E-ISSN: 2598-3105 P-ISSN: 2723-2581 http://jurnal.fh.unila.ac.id/index.php/cepalo
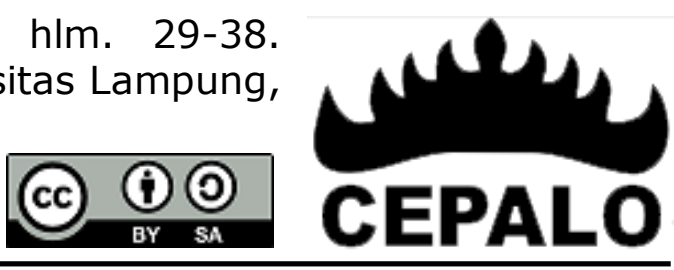

\title{
ASPEK HUKUM PERENCANAAN, PENGADAAN DAN PENEMPATAN SUMBER DAYA MANUSIA KESEHATAN DI PUSKESMAS KOTA METRO
}

\author{
LEGAL ASPECTS OF PLANNING, PROVISION AND PLACEMENT OF HUMAN \\ RESOURCES IN SOCIETY HEALTHY CENTRE (PUSKESMAS) OF METRO CITY
}

\author{
Defi Fitri Agustiani \\ Dinas Kesehatan Kota Metro \\ defiagustiani80@yahoo.com \\ FX Sumarja \\ Fakultas Hukum Universitas Lampung \\ fxsmj.unila@gmail.com \\ Budiyono \\ Fakultas Hukum Universitas Lampung \\ Byono2005@gmail.com
}

\begin{abstract}
Abstrak
Penyelenggaraan pelayanan kesehatan di puskesmas memerlukan SDM kesehatan sebagai penggerak utama. Kurangnya jumlah SDM kesehatan di puskesmas disebabkan sistem perencanaan, pengadaan dan penempatan masih perlu diperbaiki. Permasalahan: 1) Bagaimanakah perencanaan, pengadaan dan penempatan SDM kesehatan di Puskesmas Kota Metro menurut peraturan perundang-undangan yang berlaku? 2) Bagaimanakah implementasi peraturan tentang SDM kesehatan di Puskesmas Kota Metro dalam upaya meningkatkan derajat kesehatan masyarakat? Penelitian ini menggunakan pendekatan normatif dan pendekatan empiris untuk mengkaji pelaksanaan perencanaan, pengadaan dan penempatan SDM kesehatan puskesmas.

Hasil penelitian menunjukkan bahwa regulasi perencanaan, pengadaan dan penempatan SDM kesehatan tidak memberikan arahan secara jelas dan lengkap, sehingga proses penempatan SDM kesehatan tidak sesuai dengan perencanaan SDM kesehatan dan tenaga non kesehatan. Pengadaan dan penempatan SDM di Kota Metro belum sesuai pemanfaatan dan pengembangan tenaga kesehatan pada Pasal 24 UU No.36 Tahun 2014. Kebutuhan SDM kesehatan Puskesmas Kota Metro dicukupi dengan meningkatkan sarana kesehatan puskesmas, meningkatkan kompetensi dengan pendidikan dan pelatihan (Pasal 9 Ayat (1) UU No.36 Tahun 2014), merancang peraturan daerah, menempatkan SDM kesehatan top down planning dan botom up planning. Kendala: kurang dukungan dalam pengembangan SDM kesehatan, jumlah SDM kesehatan kurang dari standar, kurang sinkron antara perencanaan, pengadaan dan penempatan SDM kesehatan.
\end{abstract}

Kata Kunci: Peraturan, Perencanaan, Pengadaan, Penempatan, SDM Kesehatan.

Abstract
Providing health services in community health centers requires Human Resources as the
driver. The lack of Human Resources at the Puskesmas is due to the planning,
urement and placement systems that still need to be improved. Issues: 1) How is the


planning, procurement and placement of health human resources in the Metro City community health center according to the applicable laws and regulations? 2) How is the implementation of regulations on Human Resources in Metro City community health centers in an effort to improve the degree of public health? This study uses a normative approach and an empirical approach to assess the implementation of planning, procurement and placement of Human Resources at the community health center.

The results showed that the regulation of planning, procurement and placement of Human Resources did not provide clear and complete direction, so the placement process was not in accordance with planning. Procurement and placement of Human Resources in Metro City are not yet in accordance with the utilization and development of health workers in Article 24 of Law No.36 of 2014. The need for Human Resources in Metro City community health centers is fulfilled by improving facilities at community health centers, increasing competence with education and training (Article 9 Paragraph (1) of Law No.36 of 2014), drafting regional regulations, placing top down human resources planning and botom up planning. Constraints: lack of support in developing Human Resources, the number of health human resources is less than the standard, less synchronous between planning, procurement and placement of health human resources.

Keywords: Regulation, Planning, Procurement, Placement, Human Resources.

Cara Mengutip (How to Cite): Defi Fitri Agustiani, FX Sumarja, Budiyono "Aspek Hukum Perencanaan, Pengadaan dan Penempatan Sumber Daya Manusia Kesehatan di Puskesmas Kota Metro”, Jurnal Cepalo, 1 (1), (2017): 29-38.

DOI: https://doi.org/10.25041/cepalo.v1no1.1753

\section{A. Pendahuluan}

Menurut WHO (2006) ambang batas jumlah SDM kesehatan yang harus dipenuhi suatu negara adalah 2,28 per 1.000 populasi (untuk dokter, perawat, bidan). ${ }^{1}$ Ditinjau dari ambang batas WHO, jumlah SDM kesehatan di Indonesia masih jauh di bawah standar, hal tersebut dapat dilihat dari tabel berikut.

Table 1: Jumlah Tenaga Dan Rasio Tenaga Kesehatan di Indonesia (World Bank, 2008)

\begin{tabular}{|l|c|c|}
\hline \multicolumn{1}{|c|}{ Tenaga Kesehatan } & Jumlah & Rasio per 1.000 populasi \\
\hline Dokter & 55.379 & 0.23 \\
\hline Perawat & 308.306 & 1.37 \\
\hline Bidan & 79.152 & 0.35 \\
\hline
\end{tabular}

Memperhatikan tabel tersebut, Indonesia termasuk sebagai negara dengan kriteria jumlah dan rasio tenaga kesehatan yang belum tercukupi, dengan rasio dokter 0.23 , perawat 1.37 dan bidan 0.35. Standar jumlah dan rasio tenaga kesehatan sesuai ketentuan WHO adalah 2.28 per 1.000 populasi. Indonesia perlu meningkatkan jumlah tenaga kesehatan yang bertugas difasilitas pelayanan kesehatan. Tersedianya jumlah tenaga kesehatan yang mencukupi di Indonesia dapat menjamin hak masyarakat akan kesehatan yang bermutu dan berkeadilan. ${ }^{2}$

Menurut data tahun 2016, hasil penghitungan jumlah SDM kesehatan berdasarkan standar tenaga kesehatan dalam Permenkes No.75 Tahun 2014 tentang Puskesmas, tenaga kesehatan puskesmas berjumlah 341.536 orang. Jumlah tersebut terdiri dari 289.465 orang tenaga

\footnotetext{
${ }^{1}$ AnnaKurniati,Kajian SDM Kesehatan Di Indonesia. Jakarta: Salemba Medika, (2012), hlm. 46

${ }^{2}$ Ibid., hlm.46-47
} 
kesehatan $(84,75 \%)$ termasuk tenaga dokter dan 52.071 orang tenaga penunjang kesehatan $(15,25 \%){ }^{3}$ SDM kesehatan yang ada, tersebar di seluruh wilayah Indonesia namun belum terdistribusi secara merata di setiap puskesmas. Distribusi SDM kesehatan terkonsentrasi di Pulau Jawa, sedangkan di luar Pulau Jawa sebagian besar mengalami kekurangan. ${ }^{4}$

Salah satu fasilitas pelayanan kesehatan yang memberikan pelayanan langsung kepada masyarakat adalah puskesmas. Pasal 2 Peraturan Pemerintah Nomor 47 Tahun 2016 tentang fasilitas pelayanan kesehatan, disebutkan setiap fasilitas pelayanan kesehatan didirikan untuk melayani kesehatan berupa pelayanan promotif, preventif, kuratif dan rehabilitatif. Pelayanan tersebut termasuk pelayanan kesehatan perorangan dan pelayanan kesehatan terhadap masyarakat.Kualitas pelayanan kesehatan di puskesmas masih sering dikeluhkan oleh masyarakat. Terbatasnya SDM kesehatan menjadi salah satu faktor yang mempengaruhi kualitas pelayanan puskesmas. Kurangnya jumlah SDM kesehatan di puskesmas, menjadikan beban kerja SDM kesehatan puskesmas semakin tinggi dan tidak sesuai dengan tugas pokok serta latar belakang pendidikan. Sehingga berdampak menurunnya kualitaspelayanan puskesmas, untuk itu perlu dilakukan manajemen SDM yang nyata dan komprehensif. ${ }^{5}$

Hasil penelitian Romadhona menyebutkan bahwa sistem manajemen SDM kesehatan untuk penempatan kerja di Puskesmas Lembasada belum maksimal. Kurangnya SDM kesehatan mengakibatkan penempatan tenaga kerja tidak sesuai disiplin ilmu. Penempatan SDM kesehatan perlu diatur sesuai dengan tugas dan fungsi masing-masing profesi tenaga kesehatan. ${ }^{6}$ Penelitian lain di Kabupaten Lamongan menyatakan jumlah dan jenis SDM kesehatan yang ada sudah baik, namun belum sesuai kebutuhan berdasarkan kompetensi dan beban kerja. SDM kesehatan masih berkelompok atau tidak merata pada unit pelayanan kesehatan. ${ }^{7}$

Pasal 16 Permenkes No.75 Tahun 2014 mengatur bahwa SDM kesehatan terdiri atas tenaga kesehatan dan tenaga non kesehatan. Tenaga kesehatan terdiri dari perawat, bidan, kesehatan masyarakat, kesehatan lingkungan, ahli teknologi laboratorium, tenaga gizi dan kefarmasian. Tenaga non kesehatan adalah tenaga penunjang yang mendukung kegiatan ketatausahaan, administrasi keuangan, sistem informasi, dan kegiatan operasional lain di puskesmas. Kementerian Kesehatan mengeluarkan kebijakan terkait perencanaan SDM Kesehatan, berupa Permenkes No.33 tahun 2015 tentang pedoman penyusunan perencanaan kebutuhan SDM kesehatan yang meliputi pedoman umum, pedoman tingkat provinsi, dan pedoman tingkat kabupaten/kota menggunakan aplikasi open source (gratis) berbasis internet dalambentuk online dan offline. Aplikasi tersebut untuk memudahkan dalam pengembangan sistem informasi kedepan, terintegrasi dengan sistem informasi kesehatan yang lainnya, serta mengantisipasi daerah yang kesulitan terhadap akses jaringan internet dan dapat diterapkan pada institusi, kabupaten/kota, provinsi, dan pusat.

Memperhatikan Permenkes No. 33 tahun 2015 dan Permenkes No. 75 Tahun 2014 belum ada kejelasan tentang pengadaan SDM kesehatan (rekrutmen), sehingga dimungkinkan formasi yang dibuka untuk rekrutmen SDM kesehatan abai atau tidak memperhatikan kebutuhan SDM kesehatan yang telah disusun sebelumnya. Sehingga pada akhirnya seperti yang terjadi di Kota Metro, yaitu terjadi ketidak merataan dan kekurangan SDM kesehatan. Saat ini di Kota Metro terdapat 12 Puskesmas, dan 8 puskesmas diantaranya kekurangan tenaga kesehatan serta 6 puskesmas kekurangan tenaga non kesehatan (administrasi puskesmas). ${ }^{8}$ Artinya di Kota Metro terdapat 6 puskesmas sedang kekurangan tenaga kesehatan, dan kondisi tersebut lebih

\footnotetext{
${ }^{3}$ BPPSDM KementrianKesehatan, Laporan Kinerja Instansi Pemerintah, Jakarta: Kementrian Kesehatan RI Sekertariat Jenderal, (2016), hlm. 21

${ }^{4}$ Kurniati, Op.Cit., hlm. 52.

${ }^{5}$ Tri Puji Lestari, "Analisis Ketersediaan Tenaga Kesehatan Di Puskesmas Kota Mamuju Provinsi Sulawesi Barat Tahun 2014", Kajian, Vol. 21, No. 1, (2016), hlm. 75.

${ }^{6}$ Romadhona, KN Siregar YS, "Analisis Sebaran Tenaga Kesehatan Puskesmas Di Indonesia Berdasarkan Peraturan Menteri Kesehatan Nomor75 Tahun 2014 Tentang Puskesmas", Jurnal Kesehatan Manarang,Vol. 4 No. 2, (2018), hlm. 114-121.

${ }^{7}$ Henny Hidayanti, "Pemerataan Tenaga Kesehatan Di Kabupaten Lamongan",Cakrawala: Jurnal Litbang Kebijakan, Vol. 12 No. 2, (2018), hlm. 162-177.

${ }^{8}$ Sub Bag Keuangan Kepegawaian danUmum, Data Umum Kepegawaian Dinas Kesehatan Tahun 2017, Kota Metro: Dinas Kesehatan, (2018).
} 
diperburuk dengan mengurangi tenaga kesehatan yang ada untuk ditugaskan sebagai tenaga administrasi.

Pemerintah berupaya mencapai tujuan pembangunan di bidang kesehatan dengan melaksanakan berbagai program kesehatan. Program utama yang sangat penting dilakukan adalah perencanaan, pengadaan dan penempatan SDM kesehatan sesuai perundang-undangan yang berlaku. Jumlah SDM puskesmas yang proposional, diharapkan derajat kesehatan masyarakat dapat ditingkatkan dan pelayanan kesehatan dapat diberikan secara menyeluruh, paripurna serta terpadu bagi seluruh masyarakat. Berdasarkan uraian diatas, masalah dalam penulisan ini adalah untuk mengetahui dan menganalisa mengenai" Bagaimana perencanaan, pengadaan dan penempatan SDM kesehatan di Puskesmas Kota Metro menurut peraturan perundang-undangan yang berlaku? Dan bagaimana implementasi peraturan tentang SDM kesehatan di Puskesmas Kota Metro dalam upaya peningkatan kesehatan masyarakat?

Penelitian ini menggunakan pendekatan normatif yang mengkaji produk perundangundangan (legal approach) dan pendekatan empiris ${ }^{9}$ untuk mengkaji pelaksanaan perencanaan, pengadaan dan penempatan SDM kesehatan di Puskesmas Kota Metro. Prosedur pengumpulan data dengan cara studi pustaka dan studi lapangan (wawancara narasumber). ${ }^{10}$

\section{B. Pembahasan}

\section{Perencanaan, Pengadaan dan Penempatan SDM Kesehatan di Puskesmas Menurut Peraturan Perundang-Undangan}

Sesuai amanat Pasal 16 UU No.36 Tahun 2009 maka Pemerintah Kota Metro bertanggung jawab dan berwewenang dalam perencanaan, pengadaan, dan penempatan SDM Kesehatan yang adil dan merata bagi seluruh masyarakat. Strategi Pemerintah Kota Metro dalam melaksanakan program sumber daya kesehatan dengan cara: ${ }^{11}$

a. Melakukan konsultasi dan koordinasi program ke unit-unit dan bidang terkait.

b. Melaksanakan koordinasi lintas program dan lintas sektoral terkait dengan pelaksanaan program sumber daya kesehatan tingkat Kota Metro melalui pertemuan, sosialisasi dan pelatihan.

c. Melakukan sosialisasi dan implementasi peraturan dan kebijakan pada stakholder terkait dengan program SDM Kesehatan.

Setiap tahun hasil perencanaan SDM kesehatan Dinas Kesehatan sudah dilaporan kepada pemerintah daerah. Dalam proses pengadaan dan penempatan pegawai, SDM kesehatan selalu menjadi prioritas utama. Namun jumlah SDM kesehatan yang direkrut masih belum sesuai hasil perencanaan dan distribusinya juga menyesuaikan formasi dari pusat serta kemampuan daerah. ${ }^{12}$ Pemerintah bertanggungjawab dan berwenang dalam menyediakan SDM kesehatan dengan cara perencanaan, pengadaan dan penempatan SDM kesehatan secara adil dan merata untuk seluruh masyarakat, sesuai dengan Pasal 16 UU No.36 tahun 2009 supaya derajat kesehatan masyarakat dapat ditingkatkan dengan setinggi-tingginya.

Perencanaan, pengadaan dan penempatan SDM kesehatan sesuai ketentuan dalam UU No.36 Tahun 2014, prosesnya harus disusun secara berjenjang berdasarkan ketersediaan dan kebutuhan. Pada Pasal 17 UU No. 36 Tahun 2014 diatur proses pengadaan SDM kesehatan, yang dilaksanakan sesuai perencanaan yaitu dengan melalui pendidikan tinggi kesehatan untuk menghasilkan SDM yang berkualitas. Kota Metro sudah melaksanakan perencanaan SDM kesehatan setiap tahun sesuai kebutuhan puskesmas. Pengadaan dan penempatan SDM

\footnotetext{
${ }^{9}$ Abdulkadir Muhammad, Hukum Dan Penelitian Hukum, Bandung: Citra Aditya Bakti, (2004), hlm.134

${ }^{10}$ Mustika Zed, Metode Penelitian Kepustakaan, Jakarta: Yayasan Obor Indonesia, (2004), hlm.56

${ }^{11}$ Subag Perencanaan Informasi Program, Profil Dinas Kesehatan Kota Metro Tahun 2017, Metro Lampung: Dinas Kesehatan, (2018).

12 Joko Susanto, Interview by Defi Fitri Agustiani. Kepala Sub.Bidang Pengadaan dan Pembinaan Pegawai BKPSDM Kota Metro (Maret 1, 2019).
} 
kesehatan oleh pemerintah juga sudah dilaksanakan, tetapi implementasi dari pengadaan dan penempatan SDM kesehatan belum sesuai kebutuhan puskesmas. ${ }^{13}$

Dokumen perencanaan SDM Kesehatan puskesmas disusun menyesuaikan kondisi SDM Kesehatan yang ada dan berdasarkan standar minimal ketenagaan yang terdapat dalam Permenkes No.75 Tahun 2014, menggunakan metode Analisis Beban Kerja Kesehatan (ABKKes), metode standar ketenagaan minimal dan rasio jumlah penduduk sesuai Permenkes No.33 tahun 2015. ${ }^{14}$ Kebutuhan SDM kesehatan puskesmas dapat dipenuhi sesuai standar kebutuhan seperti yang terdapat di Pasal 16 Permenkes No.75 Tahun 2014 sesuai karakteristik wilayah kerja. Keadaan Puskesmas Kota Metro yang berkarakteristik daerah perkotaan, dalam proses perencanaan, pengadaan dan penempatan SDM kesehatan dapat dijelaskan dengan tabel berikut.

Tabel 2: Perencanaan, Pengadaan dan Penempatan SDM Kesehatan Puskesmas Kota Metro

\begin{tabular}{|c|l|c|c|c|c|}
\hline No & Jenis SDM & Rencana & Pengadaan & Penempatan & Keterangan \\
\hline 1 & Dokter Umum & 9 & 7 & 7 & Tidak sesuai \\
\hline 2 & Dokter gigi & 6 & 2 & 0 & Tidak sesuai \\
\hline 3 & Perawat & 15 & 16 & 16 & Tidak sesuai \\
\hline 4 & Bidan & 6 & 4 & 4 & Tidak sesuai \\
\hline 5 & Tenaga Kesmas & 9 & 2 & 2 & Tidak sesuai \\
\hline 6 & Tenaga Kesling & 2 & 0 & 0 & Tidak sesuai \\
\hline 7 & $\begin{array}{l}\text { Ahli Teknologi } \\
\text { Laboratorium }\end{array}$ & 4 & 0 & 0 & Tidak sesuai \\
\hline 8 & $\begin{array}{l}\text { Tenaga gizi/ } \\
\text { nutrisionis }\end{array}$ & 1 & 0 & 0 & Tidak sesuai \\
\hline 9 & Tenaga Farmasi & 4 & 5 & 5 & Tidak sesuai \\
\hline 10 & $\begin{array}{l}\text { Tenaga } \\
\text { Administrasi }\end{array}$ & 16 & 0 & 0 & Tidak sesuai \\
\hline 11 & $\begin{array}{l}\text { Pekarya } \\
\text { Kesehatan }\end{array}$ & 18 & 0 & 0 & Tidak sesuai \\
\hline & Jumlah & 90 & 36 & 36 & Tidak sesuai \\
\hline
\end{tabular}

Sumber: Data diolah dari rencana kebutuhan SDM kesehatan dan hasil seleksi kompetensi dasar Pengadaan CPNS daerah Kota Metro Tahun 2018

Melihat tabel diatas, pengadaan dan penempatan SDM kesehatan di Puskesmas Kota Metro berjumlah 36 orang tenaga kesehatan (32.4\%) dan belum sesuai dengan hasil perencanaan. Pemerintah belum melaksanakan pengadaan dan penempatan tenaga non kesehatan (tenaga administrasi) dan pekarya kesehatan untuk Puskesmas di Kota Metro. Rekrutmen/pengadaan tenaga non kesehatan juga belum ada, sehingga tugas administrasi puskesmas dilaksanakan tenaga kesehatan, yang berakibat tugas tenaga kesehatan puskesmas semakin berat. Di puskesmas terdapat tenaga kesehatan yang melaksanakan tugas jabatan dan beban kerja lebih dari dua program kesehatan, sehingga tidak dapat bekerja dengan efektif, hasil kerja tidak maksimal, dan kualitas pelayanan kesehatan ikut menurun. Tugas administrasi puskesmas semua dilaksanakan oleh kepala TU puskesmas, sebab tidak ada staf administrasi di puskesmas. ${ }^{15}$

\footnotetext{
${ }^{13}$ Subroto, Eko, interview by Defi Fitri Agustiani. Kepala Bidang Pelayanan Kesehatan Dan SDM Kesehatan Kota Metro (Januari 6, 2019).

${ }^{14}$ Subag Perencanaan InformasiProgram, Profil Dinas Kesehatan Kota Metro Tahun 2017. Dokumen, Metro Lampung: Dinas Kesehatan, (2018).

${ }^{15}$ Jauhari, Ahmad, interview by Defi Fitri Agustiani. Kepala TU Puskesmas Non Rawat Inap Mulyojati Kota Metro (Januari 6, 2019).
} 
Menurut data pada tabel 2 dan pernyataan tersebut diatas, menunjukan penempatan SDM kesehatan di Kota Metro belum memperhatikan pemanfaatan dan pengembangan tenaga kesehatan (Pasal 24 UU No.36 Tahun 2014). Penempatan SDM kesehatan dalam upaya pemerataan dan memenuhi jumlah kebutuhan tenaga di fasilitas kesehatan, wajib dilakukan dengan proses seleksi. Seleksi SDM kesehatan dilakukan melalui pengangkatan sebagai PNS, pengangkatan sebagai pegawai pemerintah dengan perjanjian kerja dan penugasan khusus, seperti yang disebutkan pada pasal 23 UU No.36 Tahun 2014.Penempatan SDM kesehatan juga menyesuaikan kebutuhan dan kemampuan setiap fasilitas pelayanan kesehatan, serta kompetensi profesi. Keahlian SDM kesehatan secara profesional diatur pada pasal 44 dan 46 UU No.36 Tahun 2014, dengan diberikan Izin berpraktik berupa Surat Tanda Registrasi (STR) dan Surat Izin Praktik (SIP).Jumlah rasio tenaga kesehatan terhadap jumlah penduduk Kota Metro dapat dijelaskanpada tabel berikut.

Tabel3: Rasio SDM Kesehatan Per100.000 Penduduk Kota Metro Tahun 2018

\begin{tabular}{|c|c|c|c|c|}
\hline \multirow[b]{2}{*}{ No } & \multirow[b]{2}{*}{ Jenis Tenaga } & \multirow{2}{*}{$\begin{array}{c}\text { JumlahSDM } \\
\text { Kesehatan }\end{array}$} & \multicolumn{2}{|c|}{ Rasio Per 100.000 Penduduk } \\
\hline & & & $\begin{array}{l}\text { Kota Metro } \\
2018\end{array}$ & $\begin{array}{c}\text { Renstra Depkes } \\
\text { 2014-2019 }\end{array}$ \\
\hline 1 & Dokter Umum & 52 & 31 & 45 \\
\hline 2 & Dokter Gigi & 8 & 6 & 13 \\
\hline 3 & Perawat & 526 & 284 & 198 \\
\hline 4 & Bidan & 215 & 129 & 120 \\
\hline 5 & Farmasi & 77 & 46 & 36 \\
\hline 6 & Kesmas & 8 & 5 & 16 \\
\hline 7 & Sanitarian & 35 & 21 & 18 \\
\hline 8 & Gizi & 26 & 16 & 14 \\
\hline 9 & Teknis Medis & 109 & 65 & 16 \\
\hline
\end{tabular}

Sumber: Data diolah dari Profil Dinas Kesehatan Kota Metro Tahun 2018

Dilihat dari rasio masing-masing jenis tenaga kesehatan per 100.000 penduduk Kota Metro, menunjukkan bahwa rasio jenis SDM kesehatan terbanyak adalah rasio tenaga perawat yaitu sebesar 284 per 100.000 penduduk (target nasional Renstra Depkes 2014-2019 adalah 198 per 100.000 penduduk). Sedangkan rasio terendah adalah tenaga Kesmas dengan rasio 5 per 100.000 penduduk (target nasional Renstra Depkes 2014-2019 adalah 16 per 100.000 penduduk). Secara umum rasio SDM kesehatan Per100.000 penduduk Kota Metro dibandingkan dengan rasio Renstra Depkes 2014-2019 adalah sudah baik, dalam artian melampaui target renstra Depkes 2014-2019.SDMkesehatan berperan penting dan berpengaruh terhadap peningkatan pelayanan kesehatan masyarakat. Seperti teori yang dikemukakan oleh A.W.Widjaja yaitu dalam suatu organisasi diperlukan penempatan SDM dengan prinsip penempatan orang yang tepat pada tempat yang tepat. ${ }^{16}$ Namun dalam realisasinya prinsip tersebut sangat sulit diterapkan, karena banyak permasalahan yang dihadapi. Perlunya perbaikan dalam manajemen SDM kesehatan dan penambahan regulasi yang mengatur perencanaan, pengadaan dan penempatan SDM kesehatan.

\section{Implementasi Peraturan Tentang SDM Kesehatan di PuskesmasDalam Upaya Meningkatkan Derajat Kesehatan Masyarakat}

Upaya Kota Metro untuk memenuhi kebutuhan SDM kesehatan di puskesmas dengan cara: ${ }^{17}$ a. Melengkapi sarana puskesmas.

\footnotetext{
${ }^{16}$ Sri Hartini, Hukum Kepegawaian Di Indonesia, Jakarta: Sinar Grafika, (2017), hlm.112

${ }^{17}$ Subag Perencanaan Informasi Program, Profil Dinas Kesehatan Kota Metro Tahun 2017, Metro Lampung: Dinas Kesehatan, (2018).
} 
Ketersediaan sarana puskesmas untuk pengelolaan SDM kesehatan secara optimal, akan menghasilkan data yang berkualitas dilihat dari jenis, jumlah dan kualifikasi sesuai kebutuhan dalam mencapai tujuan pembangunan kesehatan.

b. Meningkatkan kompetensi SDM puskesmas.

Berdasarkan Pasal 9 Ayat (1) UU No. 36 Tahun 2014 disebutkan kualifikasi pendidikan tenaga kesehatan minimum Diploma Tiga, kecuali tenaga medis. Ketentuan kompetensi masingmasing profesi tenaga kesehatan diatur dengan Peraturan Menteri Kesehatan. Untuk menghasilkan tenaga kesehatan yang bermutu sesuai standar profesi dan standar pelayanan kesehatan, diberlakukan peraturan pengadaan tenaga kesehatan melalui pendidikan tinggi bidang kesehatan sebagai SDM kesehatan puskesmas.

Ketersediaan alat-alat kesehatan modern yang tidak didukung kemampuan tenaga kesehatan di puskesmas dapat menghambat proses pelayanan kesehatan. Diperlukan pelatihan tentang operasional peralatan kesehatan dan manajemen administrasi puskesmas. Kesempatan mengikuti pelatihan diberikan pada semua SDM kesehatan puskesmas sesuai bidang tugas. Pendidikan dan pelatihan SDM kesehatan dapat dilakukan secara mandiri (izin belajar) dan melalui program bantuan pendidikan (tugas belajar). ${ }^{18}$

Di Puskesmas Rawat Inap Banjarsari Kota Metro, masih ada tenaga kesehatan yang berpendidikan setaraf SMU yaitu SMF, SPRG, SPK dan SMK. Dimulai tahun 2017, tenaga kesehatan tersebut mengikuti program percepatan pendidikan kesehatan yang diselenggarakan Kementrian Kesehatan secara bergantian. ${ }^{19}$ Pendidikan dan pelatihan sangat penting dalam profesionalitas pelayanan kesehatan. Dengan adanya peningkatan pendidikan dan pelatihan, SDM kesehatan diharapkan mampu berfikir sistematis dan logis dalam menyelesaikan masalah di bidang kesehatan dan meningkatkan produktifitas kerja.

c. Peraturan daerah tentang SDM kesehatan

Terdapat beberapa lembaga negara yang mempunyai kewenangan mengatur tentang manajemen kepegawaian dan SDM aparatur pemerintah. Di bidang kesehatan, Kementrian Kesehatan menetapkan Permenkes No.33 tahun 2015 sebagai pedoman perencanaan SDM kesehatan, karena SDM kesehatan mempunyai jabatan fungsional teknis yang berbeda dengan jabatan fungsional umum lainnya. Adanya perbedaan pada beberapa peraturan dari lembagalembaga pemerintah tentang pengaturan SDM kesehatan, pemerintah Kota Metro membuat rancangan peraturan daerah tentang manajemen pengelolaan SDM kesehatan. Namun rancangan peraturan tersebut belum ditetapkan oleh pemerintah Kota Metro, sehingga berimplikasi terhadap penempatan SDM kesehatan, yaitu terjadi penumpukan SDM kesehatan di salah satu puskesmas, sementara ada puskesmas lain yang kekurangan SDM kesehatan.

\section{d. Pedoman standar minimal SDM kesehatan.}

Penempatan SDM kesehatan menjadi wewenang pemerintah daerah yang diamanatkan dalam Pasal 26 UU No.36 Tahun 2009, idealnya SDM kesehatan terdistribusi dengan baik sehingga memenuhi kecukupan rasio jumlah penduduk yang ditentukan. Distribusi penempatan SDM kesehatan yang tepat atau sesuai perencanaan akan menghindarkan terjadinya maldistribusi. SDM kesehatan pada profesi tertentu seperti dokter, dokter gigi, apoteker dan kesling. Untuk itu diperlukan kebijakan daerah untuk mengatur perencanaan, pengadaan dan penempatan SDM kesehatan. ${ }^{20}$

Jumlah SDM kesehatan yang direncanakan merupakan hasil perencanaan sesuai pedoman dan peraturan di bidang kesehatan. Tenaga non kesehatan sangat diperlukan dalam meningkatkan pelayanan kesehatan dan jumlahnya sangat sedikit dibanding tenaga kesehatan.

\footnotetext{
${ }^{18}$ Subroto, Eko, interview by Defi Fitri Agustiani. Kepala Bidang Pelayanan Kesehatan Dan SDM Kesehatan Kota Metro (Januari 6, 2019).

${ }^{19}$ Malik, interview by Defi Fitri Agustiani. Kepala TU Puskesmas Rawat Inap Banjarsari Kota Metro (Januari 17, 2019).

${ }^{20}$ Susanto, Joko, interview by Defi Fitri Agustiani. Kepala Sub.Bidang Pengadaan Dan Pembinaan Pegawai BKPSDM Kota Metro (Maret 1, 2019).
} 
Selama ini pemerintah belum pernah merekrut tenaga non kesehatan untuk puskesmas. ${ }^{21}$ Pedoman kebutuhan tenaga non kesehatan diatur dalam pasal 26 Permenkes No.75 tahun 2014. Lampiran peraturan disebutkan secara jelas tentang jumlah minimal SDM kesehatan sesuai karakteristik wilayah kerja (perkotaan, pedesaan, terpencil, sangat terpencil) dan berdasarkan kemampuan pelayanan (rawat inap, non rawat inap).

e. Penempatan SDM kesehatan top down planning dan botom up planning.

Dalam implementasi penempatan SDM kesehatan puskesmas, pemerintah Kota Metro mengusulkan kebutuhan penambahan SDM kesehatan berdasarkan hasil perencanaan puskesmas sebagai fasilitas kesehatan dasar, untuk dilanjutkan ke pemerintah daerah provinsi dan pemerintah pusat (botom up planning). Diharapkan pemerintah pusat melakukan pengadaan dan penempatan SDM kesehatan sesuai dengan kebutuhan daerah, sehingga formasi SDM kesehatan yang direkrut adalah SDM kesehatan dengan kompetensi di bidang kesehatan dan ditempatkan difasilitas pelayanan kesehatan daerah (top down planning).Pemerintah Kota Metro sudah berupaya memenuhi kebutuhan SDM kesehatan puskesmas dengan mengikuti program pemerintah, yaitu dengan mengusulkan penambahan SDM kesehatan melalui Program Nusantara Sehat, program penugasan khusus tenaga kesehatan residen (dokter), Program Internsip Dokter, pengangkatan pegawai dengan formasi CPNSD dan Pengangkatan Pegawai Pemerintah dengan Perjanjian Kerja (PPPK).

Kendala yang dihadapi Kota Metro dalam perencanaan, pengadaan dan penempatan SDM Kesehatan yaitu:

a. Pembinaan, pengawasan dan dukungan dalam pengembangan dan pemberdayaan SDM kesehatan masih terbatas.

b. Kemampuan penyusunan perencanaan kebutuhan SDM Kesehatan masih terbatas.

c. Kurang sinkron antara pengadaan, kebutuhan dan distribusi SDM Kesehatan di fasilitas pelayanan kesehatan.

d. Ketersediaan data SDM Kesehatan di fasilitas pelayanan kesehatan belum sesuai standar minimal kebutuhan yang ditetapkan Kementrian Kesehatan.

e. Terbatasnya jumlah SDM kesehatan yang ada membuat tenaga fungsional di sarana pelayanan kesehatan melaksanakan tugas program kesehatan lebih dari satu, sehingga capaian kegiatan program kurang maksimal.

f. Jumlah fasilitas pelayanan kesehatan yang banyak menyebabkan penghitungan analisa jabatan dan analisa beban kerja menjadi berkurang banyak untuk kebutuhan SDM kesehatannya.

Banyaknya jumlah SDM kesehatan memberikan dampak yang besar bagi akses pengguna pelayanan kesehatan, yaitu:

a. Ada banyak pilihan yang tersedia sehingga pengguna layanan kesehatan dapat memilih jenis pelayanan yang diperlukan dan aksesibilitas pelayanan kesehatan dari jarak maupun waktu tempuh pengguna juga akan membaik.

b. Semakin banyak jumlah SDM kesehatan di masyarakat maka akan dapat bersaing dalam melayani kebutuhan kesehatan. Pelayanan kesehatan tersebut tidak mencari keuntungan tetapi memberikan pelayanan terbaik (service excellent) kepada masyarakat.

c. Biaya. Banyaknya jumlah SDM kesehatan yang berpraktik dapat menciptakan kompetisi tersendiri, sehingga memunculkan persaingan dalam pelayanan kesehatan dan besar kemungkinan akan memberikan biaya yang tidak terlalu mahal. Variasi biaya pelayanan kesehatan akan dicermati pengguna pelayanan dan tentunya akan memilih biaya yang terjangkau.

\section{Penutup}

\section{Kesimpulan}

\footnotetext{
${ }^{21}$ Silviani, Maria, interview by Defi Fitri Agustiani. Ka.Sub.Bag Keuangan, Kepegawaian dan Umum Dinas Kesehatan Kota Metro (Februari 6, 2019).
} 
Peraturan perencanaan, pengadaan dan penempatan SDM kesehatan tidak memberikan arahan secara jelas dan lengkap, sehingga proses penempatan SDM kesehatan tidak sesuai perencanaan dan kebutuhan SDM kesehatan di puskesmas. Pengadaan dan penempatan SDM kesehatan di Kota Metro belum memperhatikan pemanfaatan dan pengembangan tenaga kesehatan seperti yang diatur dalam Pasal 24 UU No. 36 Tahun 2014. Kebutuhan SDM kesehatan Puskesmas Kota Metro berupaya dipenuhi dengan meningkatkan sarana kesehatan puskesmas, meningkatkan kompetensi melalui program pendidikan dan pelatihan, merancang peraturan daerah tentang SDM kesehatan, serta menempatkan SDM kesehatan dengan sistem top down planning dari pusatdan kemudian disesuaikan dengan perencanaan puskesmas (botom up planning). Kendala yang dihadapai yaitu upaya pengembangan SDM kesehatan kurang mendapat dukungan, jumlah SDM kesehatan kurang dari standar, serta belum ada kesesuaian antara perencanaan, pengadaan dan penempatan SDM kesehatan.

\section{Saran}

Perlunya peraturan daerah atau peraturan walikota sebagai legalitas untuk perencanaan, pengadaan dan penempatan SDM kesehatan di puskesmas, baik untuk formasi pengadaan pegawai negari maupun pegawai kontrak.Perencanaan, pengadaan dan penempatan SDM kesehatan disesuaikan dengan kompetensi dan jenis SDM kesehatan serta standar minimal kebutuhan tenaga puskesmas, yaitu tenaga kesehatan sebagai pengelola program pelayanan kesehatan dan tenaga non kesehatan sebagai pendukung manajemen kesehatan.Diperlukan keselarasan dan keserasian antara perencanaan, pengadaan dan penempatan SDM kesehatan sesuai peraturan perundang-undangan di bidang kesehatan.

\section{A. Buku}

\section{DAFTAR PUSTAKA}

Kesehatan, B. K. (2016). Laporan Kinerja Instansi Pemerintah . Jakarta: Kementrian Kesehatan RI Sekertariat Jenderal.

Program, S. P. (2018). Profil Dinas Kesehatan Kota Metro Tahun 2017. Metro Lampung: Dinas Kesehatan.

Umum, S. B. (2018). Data Umum Kepegawaian Dinas Kesehatan Tahun 2017. Kota Metro: Dinas Kesehatan.

\section{B. Peraturan Perundang-Undangan}

Undang-Undang 36 Tahun 2009tentang Kesehatan.

Undang-Undang Nomor 36 Tahun 2014 tentang Tenaga Kesehatan.

Peraturan Pemerintah Nomor 47 Tahun 2016 tentang Fasilitas Pelayanan Kesehatan

Peraturan Menteri Kesehatan Nomor 75 Tahun 2014 Tentang Puskesmas.

Peraturan Menteri Kesehatan Nomor 33 Tahun 2015 Tentang Pedoman Penyusunan Perencanaan Kebutuhan SDM Kesehatan. 
